\title{
Edukasi pembuatan hand sanitizer berbahan alami kepada masyarakat di nagari persiapan aia manggih utara, Kecamatan Lubuk Sikaping
}

\author{
Hengki Firmanda $\odot$ \& Gian Juliano \\ Universitas Riau \\ * hengki.firmanda@lecturer.unri.ac.id
}

\begin{abstract}
Abstrak. Kegiatan pemberdayaan masyarakat dalam pembuatan hand sanitizer ini dilakukan di Nagari Persiapan Aia Manggih Utara, Kecamatan Lubuk Sikaping. WHO resmi menyatakan COVID-19 sebagai pandemi akibat semakin masifnya penyebaran COVID-19 di berbagai negara. Salah satu upaya agar terhindar dari virus tersebut adalah dengan memelihara kebersihan tangan. Saat ini banyak ditawarkan pembersih tangan berupa hand sanitizer karena penggunaannya lebih praktis. Hand sanitizer praktis digunakan dan bisa dibawa kapan saja dan dimana saja. Umumnya hand sanitzer dibuat menggunakan bahan dasar alkohol, namun penggunaan alkohol pada kulit dirasa kurang aman, selain itu di masa pandemi covid-19 ini, hand sanitizer menjadi langka di pasaran. Oleh karena itu, salah satu cara untuk mengatasi masalah tersebut adalah melakukan pembuatan hand sanitizer berbahan alami dari daun sirih dan jeruk nipis. Rumusan masalah yang muncul akibat COVID-19 di Nagari Persiapan Aia Manggih Utara yaitu bagaimana cara mengedukasi masyarakat dalam pembuatan hand sanitizer berbahan alami. Teknik yang digunakan dalam pemberdayaan masyarakat terkait pembuatan hand sanitizer berbahan alami ini adalah yaitu partisipasi masyarakat, diskusi dan sosialisasi. Berdasarkan hasil survei dan wawancara yang dilakukan pada akhir kegiatan pengabdian, $87 \%$ masyarakat telah paham cara pembuatan hand sanitizer berbahan alami, 95\% masyarakat telah paham terkait COVID19 dan gejala infeksinya, 91\% masyarakat telah paham upaya pencegahan penularan COVID-19, 88\% masyarakat telah memahami kebijakan new normal (kebiasaan normal baru), serta 97\% masyarakat mengalami penurunan pemasukan.
\end{abstract}

Kata kunci: hand sanitizer; pengabdian masyarakat; Covid-19

\begin{abstract}
This community empowerment activity in making hand sanitizers was carried out in the Nagari Persiapan Aia Manggih Utara, Kecamatan Lubuk Sikaping. WHO officially declared COVID-19 a pandemic due to the increasingly massive spread of COVID-19 in various countries. One of the efforts to avoid this virus is to maintain hand hygiene. Currently, many hand sanitizers are offered in the form of hand sanitizers because their use is more practical. Hand sanitizer is practical to use and can be carried anytime and anywhere. Generally, hand sanitzers are made using alcoholbased ingredients, but the use of alcohol on the skin is considered unsafe, besides that during the Covid-19 pandemic, hand sanitizers have become rare in the market. Therefore, one way to overcome this problem is to make a hand sanitizer made from natural ingredients from betel and lime leaves. The formulation of the problems that arise due to COVID-19 in the Nagari Persiapan Aia Manggih Utara, namely how to educate the public in making hand sanitizers made from natural ingredients, Techniques used in community empowerment related to the manufacture of hand sanitizers with natural ingredients are community participation, discussion and outreach. Based on the results of surveys and interviews conducted at the end of community service activities, $87 \%$ of the community understands how to make hand sanitizers made from natural ingredients, $95 \%$ of the community understands about COVID-19 and its symptoms of infection, $91 \%$ of the community understands efforts to prevent transmission of COVID-19, $88 \%$ of people have understood the new normal policy (new normal habits), and $97 \%$ of people have experienced a decrease in income.
\end{abstract}

Keywords: hand sanitizer ;community dedication; Covid-19

To cite this article: Firmand, $H$ \& G. Juliano. 2020. Edukasi pembuatan hand sanitizer berbahan alami kepada masyarakat di nagari persiapan aia manggih utara, Kecamatan Lubuk Sikaping. Unri Conference Series: Community Engagement 2: 84-89. https://doi.org/10.31258/unricsce.2.84-89

(C) 2020 Authors

Peer-review under responsibility of the organizing committee of Seminar Nasional Pemberdayaan Masyarakat 2020 


\section{PENDAHULUAN}

Diawal tahun 2020, dunia digegerkan dengan merebaknya virus jenis baru yaitu coronavirus (SARS-CoV-2) dan penyakitnya lazim dikenal dengan Coronavirusdisease 2019 (COVID-19) (Yuliana, 2020). Huang et al. (2020) menyatakan bahwa virus ini ditemukan pada akhir Desember 2019 di daerah pasar seafood atau live market di Wuhan, Provinsi Hubei, Tiongkok. Berdasarkan data dari Worldometer (2020) sampai tanggal 5 Juni 2020, total virus ini sudah menginfeksi 6.698.387 jiwa dan jumlah pasien meninggal sebanyak 393.142 jiwa di 218 negara di dunia. Berdasarkan data Gugus Tugas Percepatan Penanganan COVID-19 (2020) di Indonesia jumlah pasien terinfeksi hingga tanggal 4 Juni 2020 sebanyak 28.818 jiwa, pasien sembuh 8.892 jiwa dan meninggal 1.721 jiwa. Jumlah ini masih terus bertambah setiap harinya.

Riedel et al. (2019) menyatakan bahwa coronavirus adalah virus RNA dengan ukuran partikel 120-160 nm. Virus ini pertama kali menginfeksi hewan, termasuk di antaranya adalah kelelawar dan unta. Sebelum terjadinya wabah COVID-19, ada 6 jenis coronavirus yang dapat menginfeksi manusia, yaitu alphacoronavirus 229E, alphacoronavirus NL63, betacoronavirus OC43, betacoronavirus HKU1, Severe Acute Respiratory Illness Coronavirus (SARS- CoV), dan Middle East Respiratory Syndrome Coronavirus (MERS-CoV) (Riedel et al., 2019). Li et al. (2020) menyatakan bahwa COVID-19 atau Severe acute respiratory syndrome coronavirus 2 (SARS-CoV-2) adalah jenis baru dari coronavirus yang menginfeksi manusia. Coronavirus adalah koloni virus yang mampu menginfeksi sistem pernapasan manusia ataupun hewan. Pada banyak kasus, virus ini hanya menyebabkan infeksi pernapasan ringan, seperti flu. Namunvirus ini juga bisa menyebabkan infeksi pernapasan berat, seperti infeksi paru-paru (pneumonia). Kementerian Kesehatan Republik Indonesia (2020) menyatakan bahwa tanda-tanda terinfeksi virus ini yaitu demam $>380 \mathrm{C}$, batuk, ataupun sesak napas yang membutuhkan perawatan khusus. Gejala ini diperberat jika penderita adalah usia lanjut dan mempunyai penyakit penyerta lainnya, seperti penyakit paru obstruktif menahun atau penyakit jantung, maka resiko kematian akibat infeksi virus ini menjadi semakin besar.

World Health Organization (2020) resmi menyatakan COVID-19 yang disebabkan oleh SARS-CoV-2 sebagai pandemi akibat semakin masifnya penyebaran COVID-19 di berbagai negara.Salah satu upaya agar terhindar dari virus tersebut adalah dengan memelihara kebersihan tangan. Saat ini banyak ditawarkan pembersih tangan berupa hand sanitizer karena penggunaannya lebih praktis. Hand sanitizer praktis digunakan dan bisa dibawa kapan saja dan dimana saja. Umumnya hand sanitzer dibuat menggunakan bahan dasar alkohol, namun penggunaan alkohol pada kulit dirasa kurang aman karena alkohol adalah pelarut organik yang dapat melarutkan sebum pada kulit, dimana sebum tersebut bertugas melindungi kulit dari mikroorganisme (Retnosari dan Isadiartuti, 2006). Selain itu, di masa pandemi covid-19 ini, hand sanitizer menjadi langka di pasaran. Oleh karena itu, salah satu cara untuk mengatasi masalah tersebut adalah melakukan pembuatan hand sanitizer berbahan alami dari daun sirih dan jeruk nipis.

Kandungan senyawa aktif yang terdapat dalam jeruk nipis adalah limonene, linalil, lonalol, terpen, terpinol, sorbitol, saponin, dan flavonoid. Aktivitas antimikroba jeruk nipis efektif dalam membunuh bakteri gram positif dan gram negatif, seperti Candida albicans, dan juga jeruk nipis mampu menghambat perkembangan beberapa mikroorganisme seperti Staphylococcus aureus, Klebsiella pneumonia, Pseudomonas (Ismi, 2016). Sedangkan daun sirih (Piper betle Linn) mengandung senyawa flavonoid, polifenol, tanin dan minyak atsiri. Tanaman ini banyak ditemui di Indonesia sebagai tanaman obat-obatan. Hal ini disebabkan karena daun sirih mengandung minyak atsiri yang memiliki sifat anti-jamur atau membasmi kuman dan merupakan komponen yang dibutuhkan untuk menghambat bakteri patogen. Selain memiliki kemampuan antiseptik, daun sirih juga memiliki kekuatan sebagai antioksidan dan fungisida (Mulyono, 2003).Berdasarkan hasil penelitian Budiman et al. (2020) tentang pembuatan disinfektan dari bahan alami diperoleh kesimpulan bahwa jeruk nipis dan daun sirih memiliki banyak manfaat sehinga bisa digunakan sebagai antiseptik bahkan dapat diolah menjadi disinfektan alami sehingga mampu meminimalisir penyebaran virus corona melalui tangan.

Kegiatan pemberdayaan masyarakat dalam pembuatan hand sanitizer ini dilakukan di Nagari Persiapan Aia Manggih Utara, Kecamatan Lubuk Sikaping, Kabupaten Pasaman, Sumatera Barat. Masyarakat Nagari Persiapan Aia Manggih Utara mayoritas bekerja di sektor informal sebagai petani. Berdasarkan data di Buku Monografi Nagari Persiapan Aia manggih Utara (2020) jumlah petani di Nagari Persiapan Aia Manggih Utara 478 orang. Jumlah penduduk Nagari Persiapan AiaManggih Utara berdasarkan data pencacahan penduduk tahun 2020 adalah 3.225 jiwa yang terdiri dari 1.574 laki-laki, 1.651 perempuan, dengan jumlah $921 \mathrm{KK}$ (Pemerintah Nagari Persiapan Aia Manggih Utara, 2020).Masyarakat Nagari Persiapan Aia Manggih Utara sangat menjunjung tinggi adat dan tradisi yang diwariskan oleh leluhur. Sekurang-kurangnya terdapat lima upacara adat yang rutin dilakukan setiap tahun. Upacara adat tersebut yaitu: 
- Upacara Nikah Kawin

- Upacara Balimau

- Upacara Turun Ka Sawah

- Upacara Talak Bala

- Upacara Potong Rambut

Namun akibat terjadinya situasi pandemi COVID-19, maka kegiatan yang lazim dilakukan masyarakat tidak bisa dilakukan sebagaimana mestinya. Selain itu, dikarenakan masyarakat belum terbiasa dengan situasi pandemi, sehingga menimbulkan kepanikan di tengah-tengah masyarakat. Oleh karena itu, dilakukan kegiatan pemberdayaan masyarakat dalam pembuatan hand sanitizer berbahan alami sebagai salah satu cara mencegah masyarakat terinfeksi virus corona

Situasi menjadi semakin kacau akibat matinya perekonomian masyarakat di masa pandemi COVID-19 ini. Berbagai kegiatan masyarakat yang biasanya dilakukan diluar rumah jadi tidak bisa dilakukan seperti biasanya. Wabah COVID-19 ini telah membuat terjadi kekacauan baik di bidang sosial, ekonomi ataupun industri Penyebaran penyakit ini sangat cepat terjadi di masyarakat. Berbagai penelitian terus dilakukan oleh para ahli, namun vaksin yang tepat untuk mengobati infeksi virus ini belum juga didapatkan sampai saat ini. Hingga pada akhirnya World Health Organization menetapkan Coronavirus disease 2019 yangdisebabkan oleh Severe Acute Respiratory Syndrome Coronavirus-2 (SARS-CoV-2) sebagai pandemi.

Rumusan masalah yang muncul akibat COVID-19 di Nagari Persiapan Aia Manggih Utara yaitu 1) Bagaimana cara mengedukasi masyarakat dalam pembuatan hand sanitizer berbahan alami, 2) Bagaimana pengaruh pandemi COVID-19 terhadap tatanan kehidupan masyarakat, 3)Berapa persen tingkat pemahaman masyarakat menyerap informasi yang disampaikan dalam rangka memutus mata rantai penyebaran COVID19.

Tujuan dilakukannya kegiatan pengabdian ini adalah 1)melakukan edukasi pembuatan hand sanitizer berbahan alami kepada masyarakat dalam rangka membantu pemerintah bersama-sama memutus mata rantai penyebaran COVID-19, 2) mengetahui pengaruh pandemi COVID-19 terhadap tatanan kehidupan masyarakat Nagari Persiapan Aia Manggih Utara, 3) mengetahui tingkat pemahaman masyarakat dalam membuat hand sanitizer dari bahan alami.

\section{METODE PENERAPAN}

Kegiatan pengabdian masyarakat di Nagari Persiapan Aia Manggih Utara, Kecamatan Lubuk Sikaping, Kabupaten Pasaman, Sumatera Barat ini dilakukan bersama Satgas COVID-19 Nagari Persiapan Aia Manggih Utara, serta juga berkoordinasi dengan Satgas COVID-19 Nagari Aia Manggih. Tahap awal kegiatan adalah menjumpai PJ Wali Nagari Persiapan Aia Manggih Utara Ibunda Ira Dewi, SH, untuk minta izin pelaksanaan kegiatan pengabdian, serta menjumpai PJ Wali Nagari Aia Manggih Bapak Arif Afandi, S.STP. Permulaan kegiatan dilakukan rapat koordinasi bersama Relawan COVID-19 Nagari Persiapan Aia Manggih Utara, relawan COVID-19 Nagari Aia Manggih, Bidan Desa Nagari Aia Manggih, serta pendamping desa. Rapat ini dipimpin oleh Wali Nagari Aia Manggih, Bapak Arif Afandi, S.STP. Materi rapat ini difokuskan pada upaya pencegahan penyebaran COVID-19 di Nagari Persiapan Aia Manggih Utara, dan Nagari Aia Manggih serta kebijakan pemerintah terkait infeksi COVID-19.

Teknik yang digunakan dalam pemberdayaan masyarakat terkait pembuatan hand sanitizer berbahan alami ini adalah yaitu:

1. Teknik partisipasi masyarakat untuk menyebarluaskan vidio tutorial pembuatan hand sanitizer berbahan alami melalui media sosial ataupun youtube.

2. Teknik pengisian angket dan wawancara untuk mengetahui berapa persen tingkat pemahaman masyarakat dalam menyerap informasi yang disampaikan, serta untuk mengetahui tanggapan masyarakat terhadap program-program yang telah dilakukan selama kegiatan pengabdian.

Untuk mengetahui tingkat keberhasilan dari kegiatan yang dilakukan dalam rangka mencegah penyebaran COVID-19 di Nagari Persiapan Aia Manggih Utara, maka diakhir kegiatan dilakukan:

1. Tingkat ketercapaian sasaran program diketahui berdasarkan survei (pengisian kuisioner) dan wawancara kepada masyarakat Nagari Persiapan Aia Manggih Utara. Survei (pengisian kuisioner) dan wawancara dilakukan dalam dua tahap, tahap pertama ketika kegiatan pengabdian belum dilakukan, dan tahap kedua dilakukan diakhir kegiatan pengabdian. Survei (pengsian kuisioner) dan wawancara tahap pertama terkait tingkat pemahaman masyarakat mengenai gejala infeksi COVID-19, tindakan pencegahan, serta dampak COVID-19 terhadap perekonomian masyarakat. Survei dalam bentuk pengisian angket dan wawancara 
terkait COVID-19 ini dilakukan kepada 200 responden yang tersebar di Nagari Persiapan Aia Manggih Utara.

2. Survei dalam bentuk pengisian angket dan wawancara tahap kedua dilakukan diakhir kegiatan pengabdian terkait respon masyarakat terhadap program-program yang dijalankan selama menjalankan kegiatan pengabdian, serta terkait tingkat pemahaman masyarakat mengenai COVID-19, upaya pencegahannya, dan tingkat pemahaman masyarakat dalam membuat hand sanitizer berbahan alami. Survei dan wawancara tahap kedua ini dilakukan kepada 200 responden yang tersebar di Nagari Persiapan Aia Manggih Utara.

\section{HASIL DAN KETERCAPAIAN SASARAN}

Potensi utama pemberdayaan masyarakat Nagari Persiapan Aia Manggih Utara terkait upaya memutus mata rantai COVID-19 adalah pembuatan hand sanitizer alami dari campuran air rebusan daun sirih dan air jeruk nipis. Hal ini dikarenakan di daerah Nagari Persiapan Aia Manggih Utara bisa dijumpai kedua jenis tanaman tersebut di kebun-kebun ataupun lingkungan rumah warga, baik itu tanaman daun sirih ataupun jeruk nipis. Selain itu, proses pembuatan hand sanitizer ini pun sangat sederhana dengan menggunakan alat-alat dapur seperti panci, pisau, baskom yang umumnya setiap rumah memilikinya, serta proses pembuataannya mudah dipahami. Setelah dibuat, hand sanitizer ini dimasukkan ke botol sprayer. Hand sanitizer ini lebih praktis digunakan untuk mensterilkan tangan dari virus-bakteri yang menempel pada tangan dikarenakan ukurannya yang kecil serta mudah dibawa. Berikut merupakan foto tanaman daun sirih dan jeruk nipis dihalaman rumah warga.

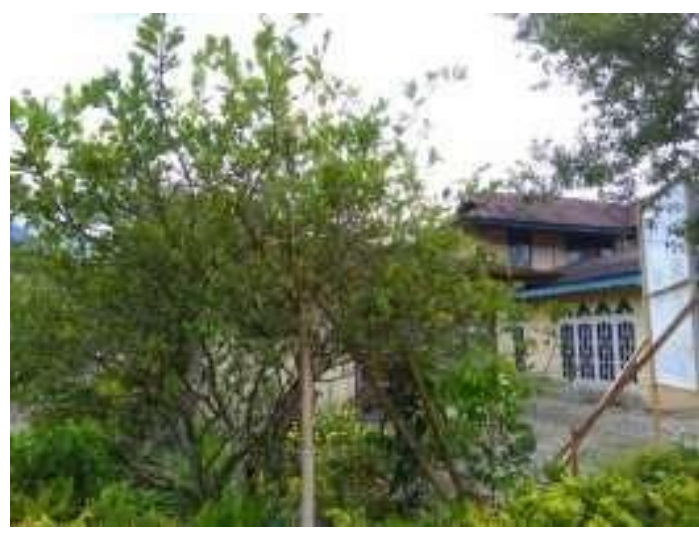

Gambar 1. Tanaman jeruk nipis

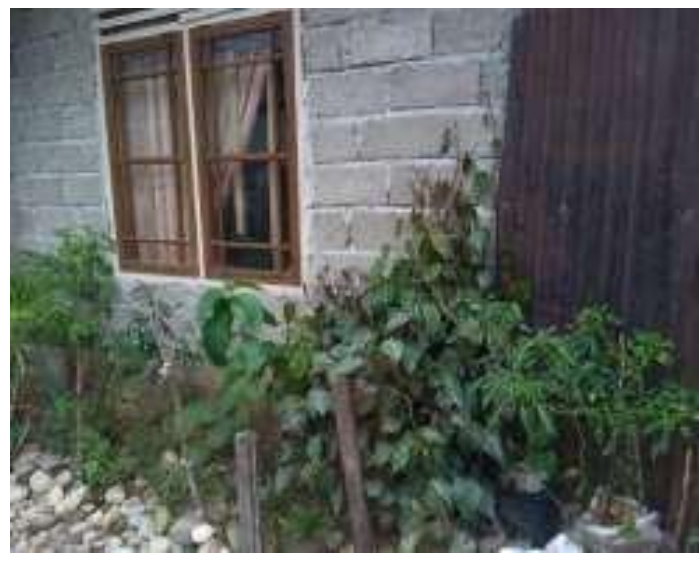

Gambar 2. Tanaman sirih

Kegiatan pemberdayaan masyarakat ini dilakukan dengan cara melakukan pembuatan hand sanitizer berbahan alami dari air rebusan daun sirih dan air perasan jeruk nipis, lalu merekam setiap tahapan pembuatan hand sanitizer tersebut. Setelah jadi, vidio tutorial pembuataanya disebarluaskan kepada masyarakat, baik melalui whatsapp ataupun youtube agar bisa dipelajari dan diterapkan dirumah. Alasan dilakukannya edukasi 
tidak tatap muka secara langsung adalah untuk mencegah terjadinya kerumunan masyarakat dan memperkecil resiko penularan COVID-19.

Setelah itu, dilakukan pengisian angket dan wawancara untuk mengetahui berapa persen tingkat pemahaman masyarakat dalam menyerap informasi yang disampaikan, serta untuk mengetahui tanggapan masyarakat terhadap program-program kegiatan yang telah dilaksanakan.Hasil dari pengisian angket dan wawancara tahap pertama dan kedua terkait pemahaman masyarakat mengenai COVID-19 dapat dilihat pada Tabel 1 dan Tabel 2.

Tabel 1. Hasil kegiatan pengisian angket dan wawancara tahap pertama (sebelum kegiatan pengabdian dilakukan)

\begin{tabular}{|c|c|c|c|c|}
\hline \multirow[b]{2}{*}{ Pertanyaan } & \multicolumn{3}{|c|}{ Hasil } & \multirow[b]{2}{*}{ Tidak Jawal } \\
\hline & Paham & $\begin{array}{l}\text { Kurang } \\
\text { paham }\end{array}$ & $\begin{array}{l}\text { Tidak } \\
\text { paham }\end{array}$ & \\
\hline $\begin{array}{l}\text { Pemahaman masyarakat terkait Covid-19 dan } \\
\text { gejala infeksinya }\end{array}$ & $50 \%$ & $30 \%$ & $18,5 \%$ & $1,5 \%$ \\
\hline $\begin{array}{l}\text { Pemahaman masyarakat mengenai prosedur } \\
\text { pencegahan Covid-19 }\end{array}$ & $52,5 \%$ & $36,5 \%$ & $9,5 \%$ & $1,5 \%$ \\
\hline Pemahaman masyarakat mengenai new normal & $51 \%$ & $33,5 \%$ & $13 \%$ & $2,5 \%$ \\
\hline $\begin{array}{l}\text { Dampak Covid-19 terhadap perekonomian } \\
\text { masyarakat }\end{array}$ & $\begin{array}{l}\text { Tetap } \\
4,5 \%\end{array}$ & $\begin{array}{l}\text { Menurun } \\
94,5 \%\end{array}$ & $\begin{array}{l}\text { Meningkat } \\
1 \%\end{array}$ & - \\
\hline
\end{tabular}

Tabel 2. Hasil kegiatan pengisian angket dan wawancara tahap kedua (setelah kegiatan pengabdian dilakukan)

\begin{tabular}{lllll}
\hline & \multicolumn{3}{c}{ Hasil } \\
\cline { 2 - 4 } Pertanyaan & Paham & $\begin{array}{l}\text { Kurang } \\
\text { paham }\end{array}$ & $\begin{array}{c}\text { Tidak } \\
\text { paham }\end{array}$ & Tidak Jawab \\
\hline $\begin{array}{l}\text { Pemahaman masyarakat mengenai pembuatan } \\
\text { hand sanitizer berbahan alami }\end{array}$ & $87 \%$ & $10 \%$ & $3 \%$ & - \\
$\begin{array}{l}\text { Pemahaman masyarakat terkait Covid-19 dan } \\
\text { gejala infeksinya }\end{array}$ & $95 \%$ & $3 \%$ & $2 \%$ & - \\
$\begin{array}{l}\text { Pemahaman masyarakat mengenai prosedur } \\
\text { pencegahan Covid-19 }\end{array}$ & $91 \%$ & $7 \%$ & $2 \%$ & - \\
$\begin{array}{l}\text { Pemahaman masyarakat mengenai new normal } \\
\text { Dampak Covid-19 terhadap perekonomian }\end{array}$ & $88 \%$ & $10 \%$ & $1 \%$ & $1 \%$ \\
$\begin{array}{l}\text { masyarakat } \\
\text { Tetap }\end{array}$ & Menurun & Meningkat & - \\
\hline
\end{tabular}

\section{KESIMPULAN}

Berdasarkan kegiatan pengabdian yang telah dilakukan di Nagari Persiapan Aia Manggih Utara, dapat disimpulkan bahwa:

1. Untuk mencegah penularan COVID-19, telah dilakukan edukasi pembuatan hand sanitizer berbahan alami kepada masyarakat dalam bentuk pembuatan vidio tutorial pembuatan hand sanitizer. Vidio tersebut disebarluaskan ke masyarakat melalui whatsapp ataupun youtube. Alasan kegiatan ini dilakukan tidak tatap muka secara langsung dengan masyarakat adalah untuk mencegah kerumunan masa serta memperkecil resiko penyebaran virus corona. Masyarakat cukup mudah untuk memahami langkah kerja pembuatannya, 
serta alat dan bahan yang dibutuhkan tidak sulit untuk dijumpai. Selain itu juga dilakukan sosialisasi dan contoh langsung dilapangan terkait upayamencegah penularan COVID-19 di tengah-tengah masyarakat.

2. Masyarakat Nagari Persiapan Aia Manggih Utara mengalami tekanan psikis atau kepanikan karena belum terbiasa dengan situasi pandemi. Selain itu, akibat kebijakan PSBB yang diterapkan pemerintah di awal kemunculan kasus ini, perekonomian masyarakat mengalami hambatan/kemunduran. Sehingga untuk tetap mempertahankan keberlangsungan hidupnya, masyarakat terpaksa melanggar peraturan PSBB dan tetap beraktivitas di luar rumah.

3. Berdasarkan survei dan wawancara yang dilakukan di Nagari Persiapan Aia Manggih Utara pada akhir kegiatan pengabdian, $87 \%$ masyarakat telah paham cara pembuatan hand sanitizer berbahan alami, $95 \%$ masyarakat telah paham terkait COVID-19 dan gejala infeksinya, 91\% masyarakat telah paham upaya pencegahan penularan COVID-19, 88\% masyarakat telah memahami kebijakan new normal (kebiasaan normal baru), serta $97 \%$ masyarakat mengalami penurunan pemasukan.

\section{UCAPAN TERIMAKASIH}

Penulis mengucapkan terima kasih kepada: (1) Bapak Prof. Dr. Ir. Aras Mulyadi, DEA, selaku rektor Universitas Riau, (2) Ketua LPPM Universitas Riau Bapak Prof. Dr. Almasdi Syahza, SE., MP, beserta jajarannya,(3) Tim Pokja Kukerta UNRI yang telah membimbing selama menjalankan kegiatan pengabdian,(4) Ibunda Ira Dewi, SH, selaku PJ Wali Nagari Persiapan Aia Manggih Utara, (5) Tim Relawan COVID-19 Nagari Persiapan Aia Manggih Utara yang telah membantu selama menjalankan kegiatan pengabdian.

\section{DAFTAR PUSTAKA}

Budiman., A. Y. Arisman., Sulfidar dan M. Arsyad. 2020. Pembuatan Disinfektan dari Bahan Alami untuk Meminimalisir Penularan Covid-19. Wellnes and Healthy Magazine, 2(2), 211-218.

Gugus Tugas Percepatan Penangan COVID-19 Pusat. 2020. Corona.go.id. Diakses tanggal 5 Juni 2020.

Huang, C., Y. Wang., X. Li., J. Zhao., G. Zan dan G. Fan. 2020. Clinical features of patients infected with 2019 novel coronavirus in Wuhan. The Lancet. 24 Januari 2020.

Ismi, S. 2016. Perubahan Dimensi Hasil Cetakan Alginat Setelah Dilakukan Perendaman dalam Air Perasan Jeruk Nipis (Citrus aurantifolia S.). Repositori Institusi Universitas Sumatera Utara, 10-11

Kementerian Kesehatan Republik Indonesia. 2020. kemkes.go.id. Diakses tanggal 16 Juni 2020.

Li, G., Y. Fan., Y. Lai., T. Han., Z. Li dan P. Zhou. 2020. Coronavirus infections and immune responses. Journal Med Virology, 92(4), 424-32.

Mulyono, M. R., 2003. Khasiat dan Manfaat Daun Sirih Obat Mujarab dari masa ke Masa. AgroMedia Pustaka. Jakarta.

Pemerintah Nagari Persiapan Aia Manggih Utara. 2020. Buku Monografi Nagari. Nagari Persiapan Aia Manggih Utara. Pasaman.

Retnosari dan Isadiartuti, D. 2006. Studi Efektivitas Sediaan Gel Antiseptik Tangan Ekstrak Daun Sirih (Piper betle Linn.). Majalah farmasi Indonesia.

Riedel, S., S. Morse., T. Mietzner., S. Miller., Jawetz, Melnick, dan Adelberg's Medical Microbiology. 2019. McGrawHill Education/Medical. New York.

Yuliana. 2020. Corona virus diseases (COVID-19); Sebuah Tinjauan Literatur. Wellness and Healthy Magazine. 2(1), $187-192$.

Worldometer. 2020. www.worldometer.info. Diakses tanggal 5 Juni 2020.

World Health Organization. 2020. Director-General's remarks at the media briefing on 2019-nCov on 11 Feb 2020. Cited Feb 13rd 2020. Available on: https://www.who.int/dg/speeches/detail/who-director-genera 